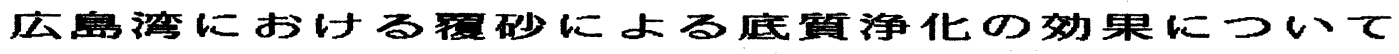

\begin{tabular}{|c|c|c|c|}
\hline 運輸省第三港湾建設局 & 正会員 & 柿川 & \\
\hline & & 城戸 & \\
\hline & & 川崎 & \\
\hline & & 溝端 & \\
\hline
\end{tabular}

1.はじめに

近年我が国の多くの閉鎖性内湾においては、外海との海水交換が弱いうえに、背後地からの有機物質等の流入負荷 によって水筫、底質が悪化し、水産漁場をはじめとする海域利用上、あるいは境境保全上しばしば重大な問題を引き 起こしてきた。

昭和 40年代後半に入って、排出規制の強化や排水処理施設の整備進捗等により流入負荷量は一時のピーク時を下回 るようになったが、依然として赤湖の発生が多く報告されるなど、必ずしも水質改善がなされたとは言い難い。

このため、運䑳省第三港流建設局では、閉銷性内湾であり污染度の進んだ広島湾（呉湾）において、海域環境を改 善する报本策の一つとして考えられる覆砂工法による試臨区域を設けその改善教果を追跡している。

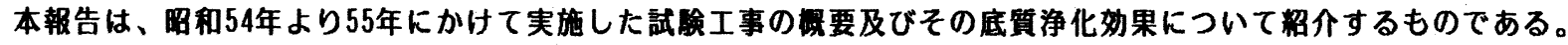

\title{
2. 広岛湾の污染実態
}

広島湾は、屋代島と倉橋島に囲まれた面積 $946 \mathrm{~K}$ 、容積 $24.2 \mathrm{~K}$ 、平均水深 $25.6 \mathrm{~m}$ の海域である。湾内には、多数の 島々が点在し、さらに太田川（淡水流入量、夏季 $100.6 \mathrm{~m} / \mathrm{sec}$ 、冬季 $76.1 \mathrm{~m} / \mathrm{sec}$ ）をはじめ多くの河川が流入し ている。このため、広島湾はこれらの河川を通じて流域に集中した人口、産兹からの污染物質の負荷を受けている。

流況は、複雓な地形を反映し、上げ潮時、柱島水道から広島湾を時計回りに流れ、呉浡の方向へ扳け、下げ潮時、 貟湾から広島湾を反時計回りに流れ、柱島水道を抜ける。桓流は、柱島と倉橋島の間を北上して湾内に流入する。湾 奥部及び與湾では恒流は弱く、やや東流する㑯向がある。

風向は、䀰で北東〜北北東と西南西〜西の風が卓越しており、風速は $5 \mathrm{~m} / \mathrm{sec}$ 末满がほとんどである。

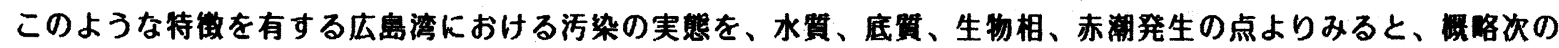
ようなことが言える。

\section{1) 水貿}

表層水質の分布は、図一1に示すとおりであり、透明度は湾奥沿岸部で $2 m$ 以下と低い值を示しており、海水の污

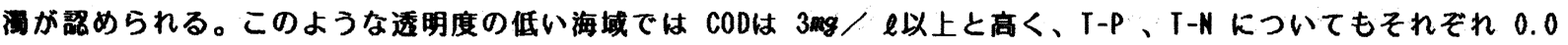

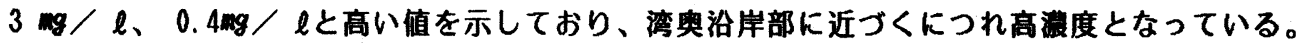

また、湾内の一次生産の指標であるクロロフィルaについてみても、宮島、西能美島と江田島に囲まれた㴒奥部で は、 $5 \mu \mathrm{g} / \ell$ 以上であり、栄盖塩項目と同じく、湾奥沿岸に近づくにつれ高㵊度となっている。
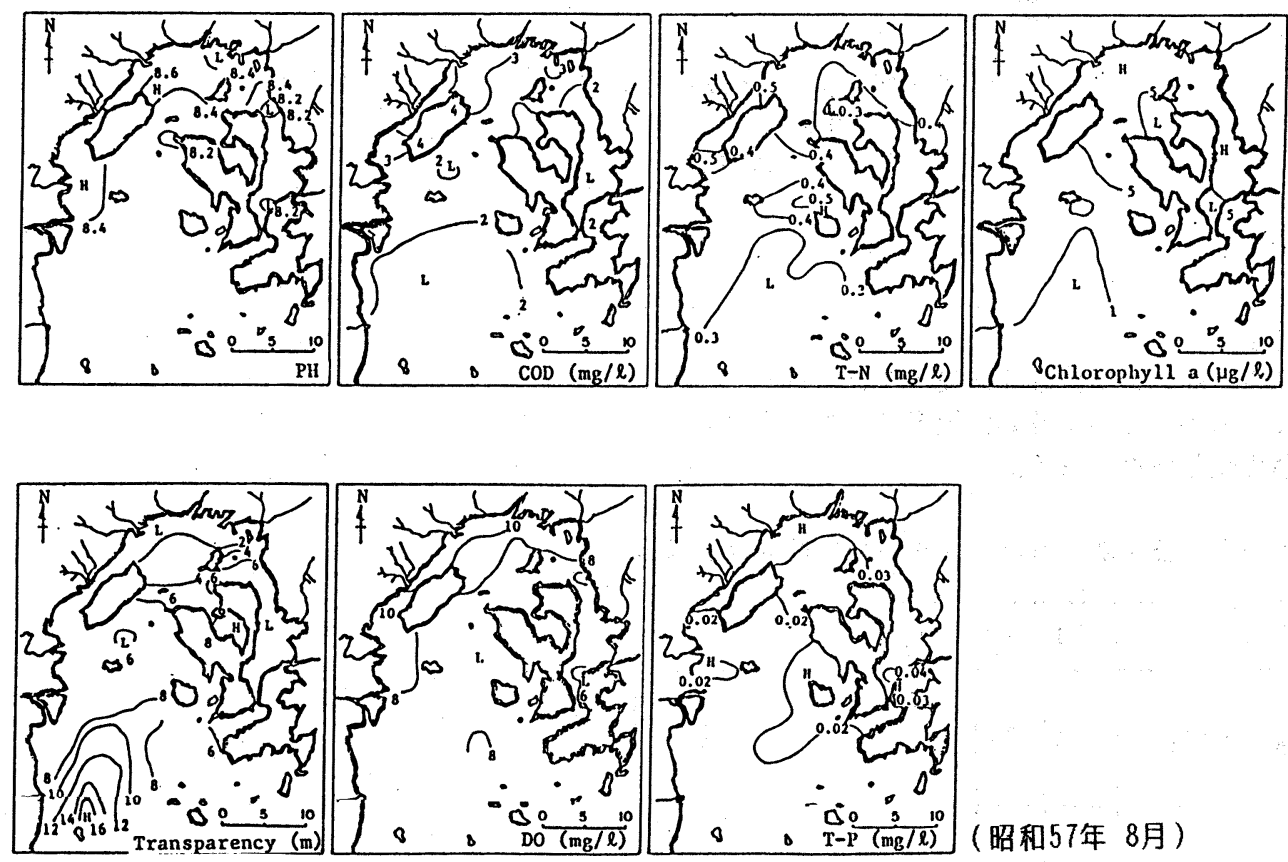

\section{図-1＼cjkstart表層水質の現況 （昭和57年度広岛湾全域污染実態浬查）}


2) 底䨘

表層底質の現況は、江田島湾、具湾で有機物の含有量が高い。表層底質の有機物污染の分布をよりわかりやすくす るため、C $0040 \mathrm{mg} / \mathrm{g} 、$ 強熱隇量 $10 \%$ 、硫化物 $0.5 \mathrm{mg} / \mathrm{g}$ 以上の海域を図示すると、図一2のとおりである。これら の共通領域は、呉湾、江田島湾、湾奥治岸城であり、特に污染が進行している。

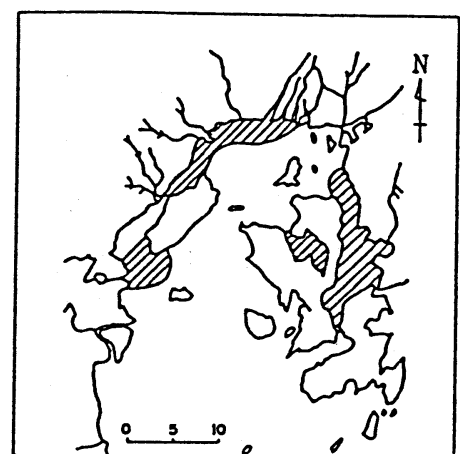

$\operatorname{COD} 40 \mathrm{mg} / g$ 以上の区域

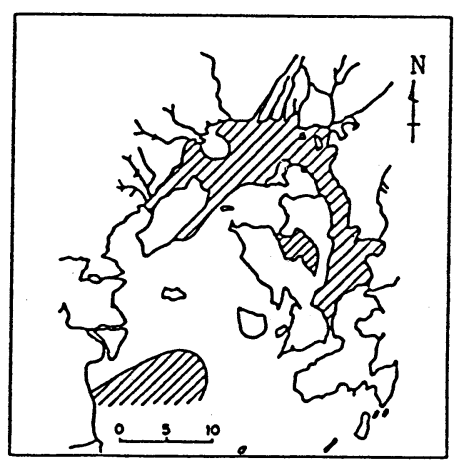

強熱減量10\%以上の区域

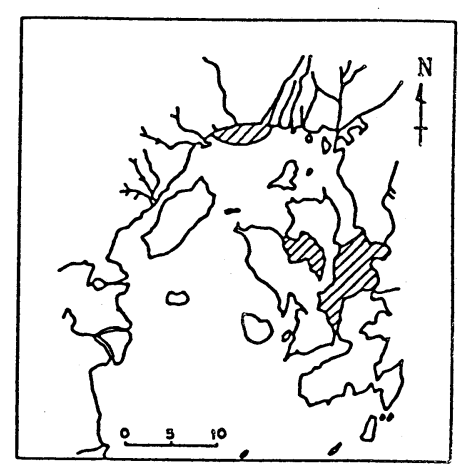

硫化物 $0.5 \mathrm{mg} / \mathrm{g}$ 以上の区域

(昭和57年 8 月)

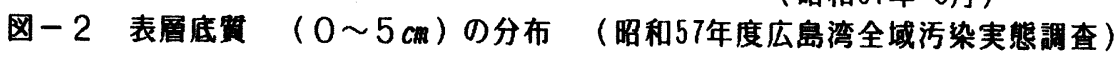

3) 生物相

広島湾の夏季におけるプランクトンの出現状況は、植物 プランクトンの絴胞数の分布をみると、江田島湾、湾奥沿 岸域、與湾で多い傾向にあり、種類数は湾奥沿岸域、與湾 で多く20種類を越えており、江田島湾では10種類以下と少 なくなっている。助物プランクトンの総種類数は56種類、 平均個体数は $3.5 \times 10^{4}$ 個体 $/ m$ であり、個体数は宮島周 辺で多い傾向がみられた。湾奥沿岸部をみると、出現する 種類が限られており、多様性の低い水域であることがわか る。

また、広島㴒の夏季における底生生物相の分布を図一-3 に示す。生物量は㴒奥沿岸域で多い傾向にあるが、そのほ とんどが多毛類で占められていることから、有機污潈が進 行していることがわかる。

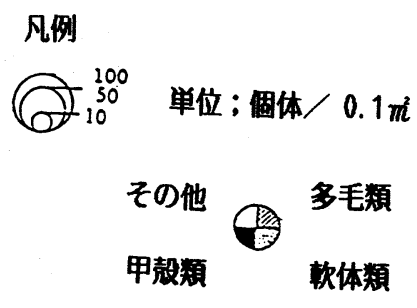

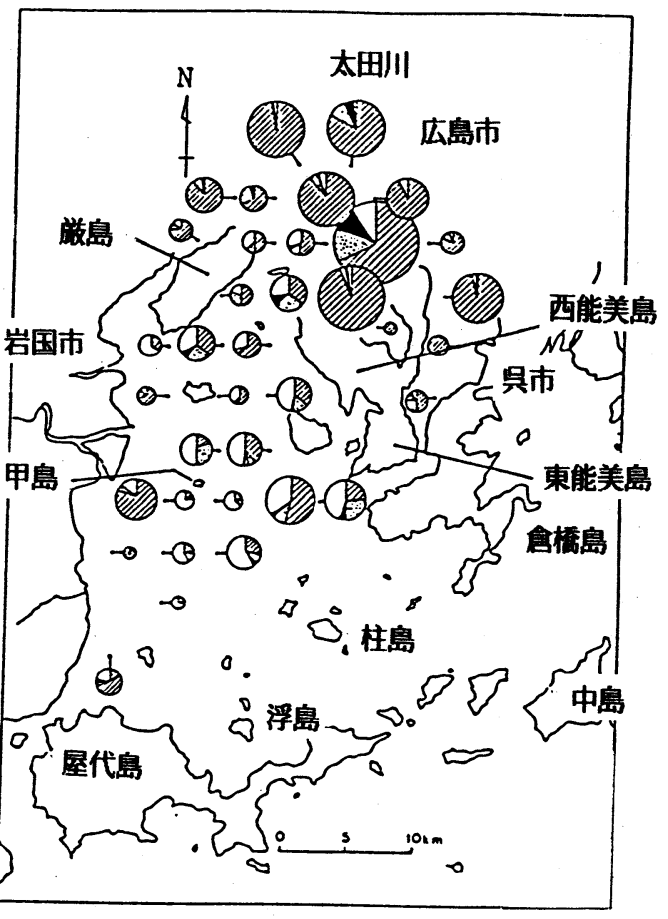

目一３底生生物の分類群別個体数分布 (昭和57年度広島湾全域污染実態調査)（昭和57年 8月）

4) 赤潮の発生

安芸满における赤潮の発生件数及び被害件数を表一 1 に示す。発生件数は、昭和 40 年代後半に比べると最近では少 なくなっているものの、なお年間10件程度は発生している。赤潮の発生域は湾奥沿岸から呉湾にかけてであり、この 海域は例年赤潮の発生がみられる。

\section{表ー1 安芸雀における赤潮の発生件数及び被害件数 「瀬戸内海の環境保全より」}

\begin{tabular}{|c|c|c|c|c|c|c|c|c|c|c|c|c|c|c|c|}
\hline 年 次 & 71 & 72 & 173 & 174 & 175 & 76 & 177 & 178 & 179 & 180 & 81 & $' 82$ & 183 & 184 & 185 \\
\hline 赤潮発生件数 & 11 & 11 & 14 & 24 & 18 & 14 & 18 & 8 & 12 & 8 & 13 & 11 & 14 & 10 & 8 \\
\hline 赤潮による被害数 & & & 1 & 2 & 4 & & 2 & & 1 & & & & & & \\
\hline
\end{tabular}




\section{3. 底質净化事業の考え方}

前述したように広島湾では環境污染が進行しており、その対策として流入負荷の削減と併せて、海域の自浄能力を 回復する必要がある。後者について、栄盖塩類の溶出負荷を削減するため、底泥を媒介とした栄養塩䫏の悪循環を断 ち切る方策として考えられたのが底質浄化事業である。具体的には、富栄盖化に富んだ底泥を除去し、または被覆す ることにより、底泥からの栄養塩類の溶出を抑さえ、底層水の貧酸素化を防ぎ、ひいては海域の自浄能力を回復しよ うとするものである。

本格的な底質浄化事業に着手するにあたって、広島湾において、小規模の稪砂による試監工事を行い、環境改善奻 果についての追跡調查を実施している。以下にその概要を述べる。

\section{4. 試嗱工事}

1) 工事瀷要

（1）工事場所は江旧島南東岸沖の閉鎖性の強い 污染の進んだ海域を選定した。

（2）覆砂材は與湾より約 $50 \mathrm{Km}$ 離れた海城から産 出するシルト分以下の細粒分を含まない海砂 を使用した。

（3）覆砂厚は昭和 54 年度施工区域が $50 \mathrm{~cm} 、 55$ 年 度施工区域が $30 \mathrm{~cm}$ である。
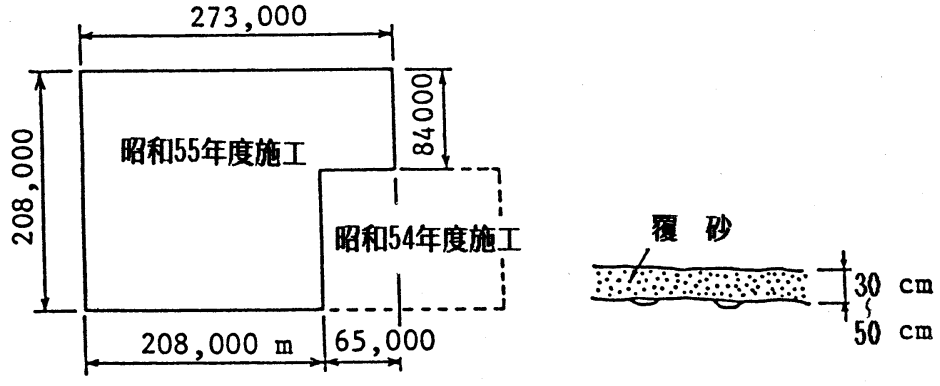

\section{図-4＼cjkstart試検工事の規模及び形状}

2）施行方法及び精度

工事の施行は、コンベアバージ、バージアンローダーの両方式により実施した。施行後、柱状サンプルの採取、ポ 一ル貫入による計测を行った結果、平均覆砂厚は覆砂目標值に対して、99\% 108\%の籁囲内にあり、計画された覆砂 厚が確保されたと判断できる。

\section{5. 奻果追跡調查}

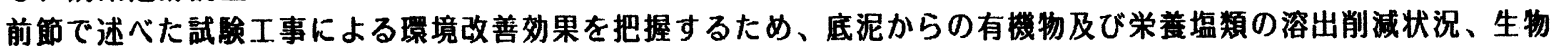
相の回復状況等について昭和54年か561年にかけて、奻果追跡調查を行った。奻果追跡調查の测点配置を図ー 5 に示 す。

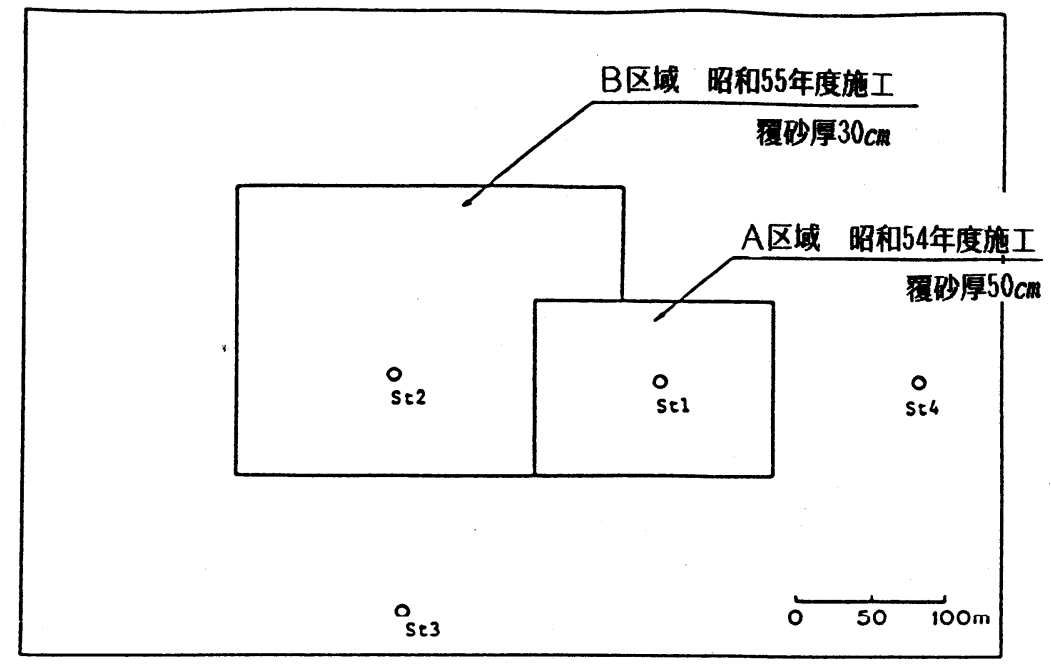

圀一５＼cjkstart覆砂試䀫区域内外の調查测点配置

1) 調查内容

（1）底質・間隙水

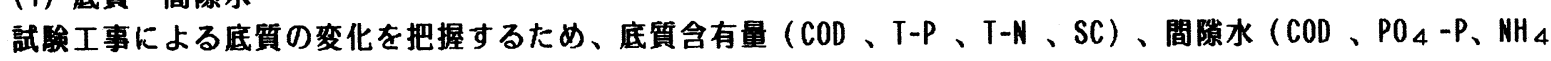
一N)を調查した。

(2) 溶出速度

武䣲工事による底泥からの有機物及び栄盖塩類の溶出速度 $\left(\mathrm{COD} 、 \mathrm{PO}_{4}-\mathrm{P} 、 \mathrm{NH}_{4}-\mathrm{N}\right)$ の変化を把握するため、現地 試唭を行った。 
（3）底生生物

試験工事における生物相の変化を把提するため、底生生物の種類数及び個体数を調査した。

2)拥查結果

（1）底貿 ・ 間隙水

覆砂試験区域内外の表層泥の底質の変化を図-6に示す。覆砂層（A区、B区）の底質は、区域外の底質に比べて 有嘰物及び栄養塭は、かなり低く抑えられており、その奻果は、6年程度経過しても十分維持されている様子がわか る。
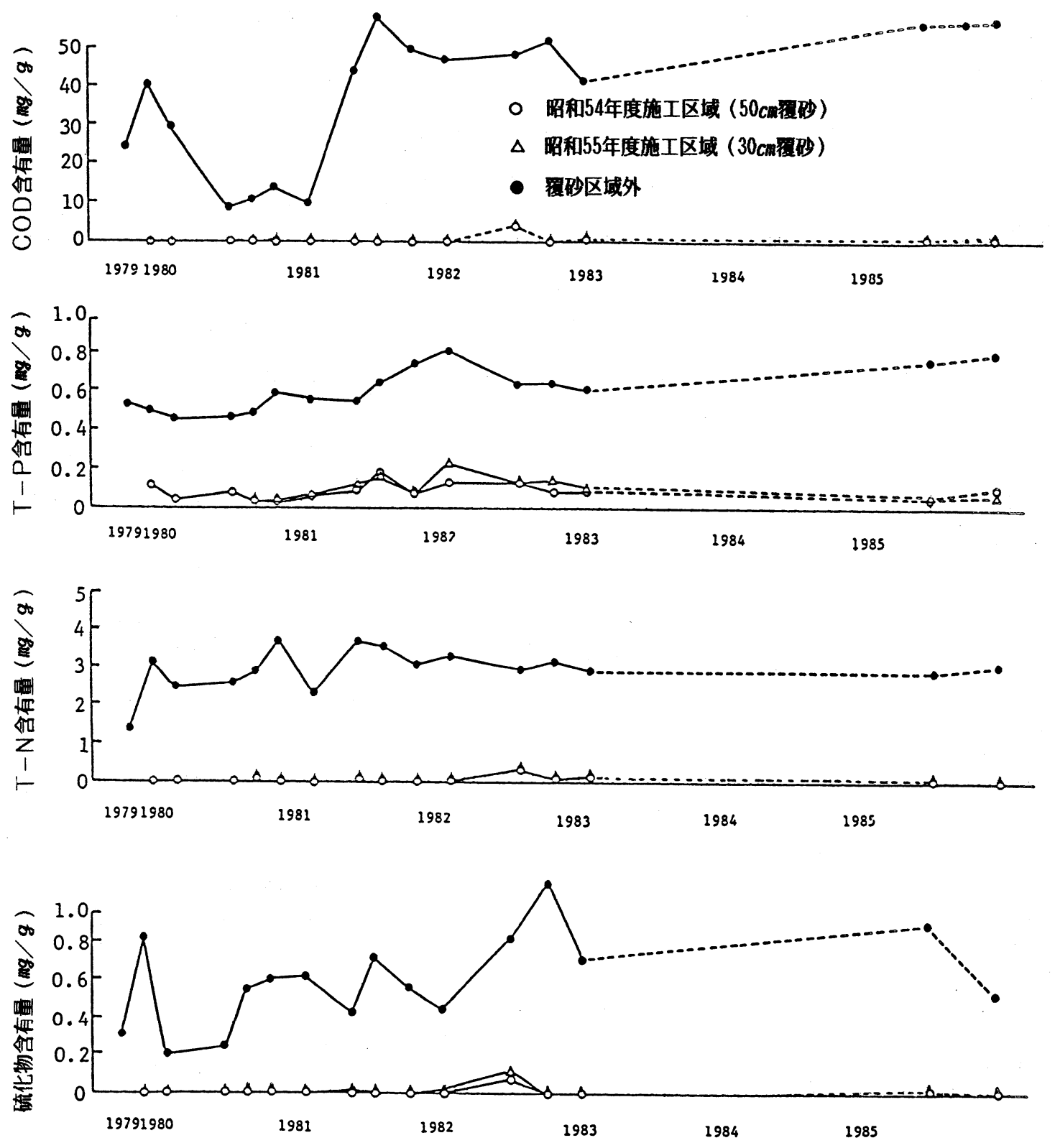

図-6 覆砂区域内外の表層泥の底質変化

また、覆砂試験区域内外の底質の鈶直分布の経時変化を図ー 7 に示す。覆砂面上に浮泥が $10 \mathrm{~cm}$ 程度推積しており、 時間の経過とともに覆砂区域表層で、浮泥の推積により底質の含有量がやや高くなってきているが、在来泥表層に比 べれば低い值であることがわかる。次に、底泥間䅈水の水質の鉛直分布の経時変化を図一8に示す。この結果をみる

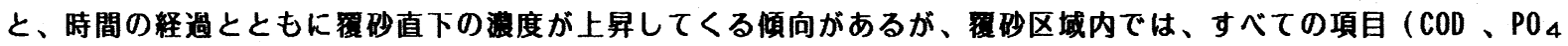
$\left.-P 、 N_{4}-N\right)$ とも低く保たれている様子がわかる。 


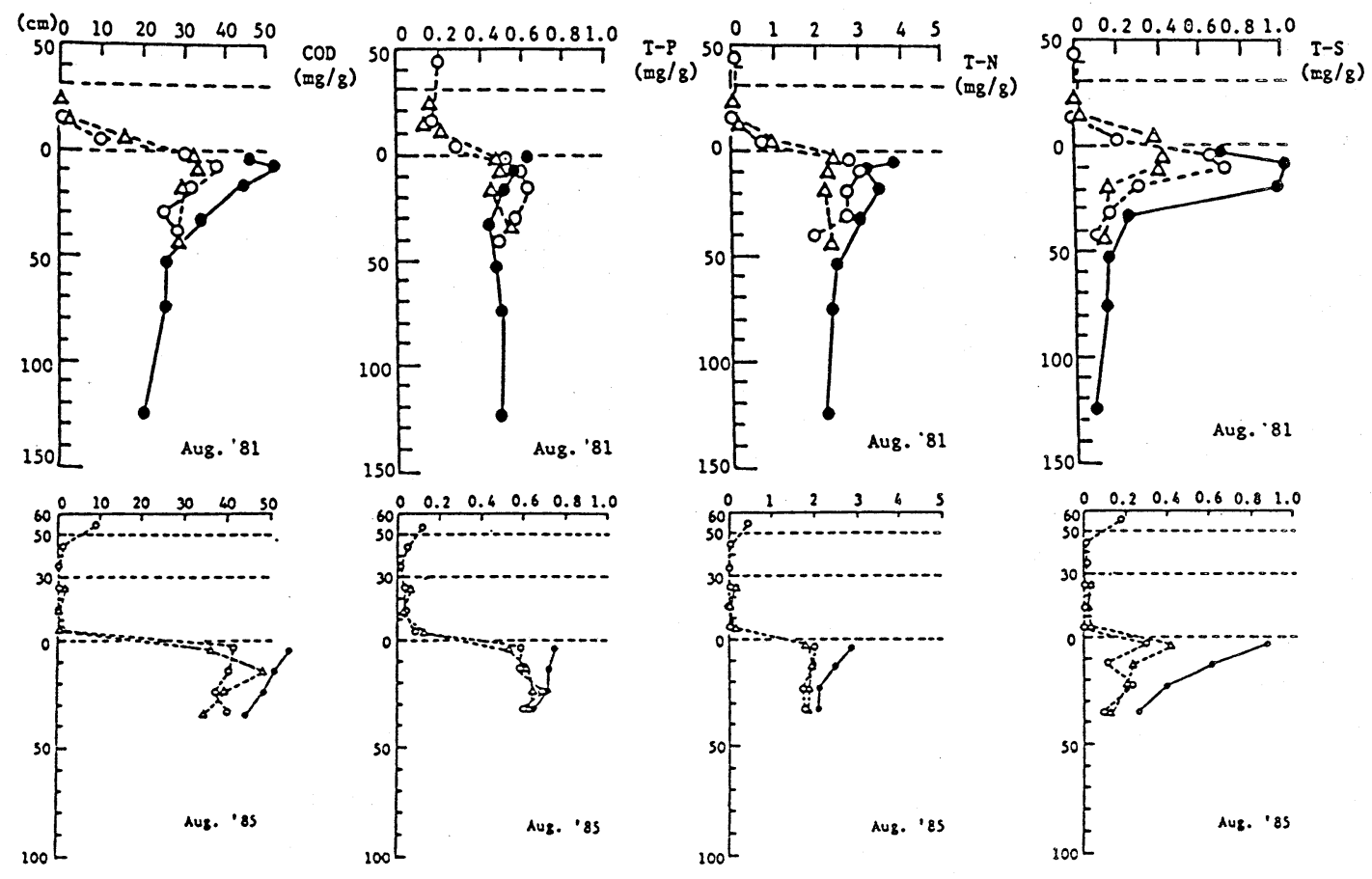

図- 7 覆砂区域内外の底質含有量鈶直分布
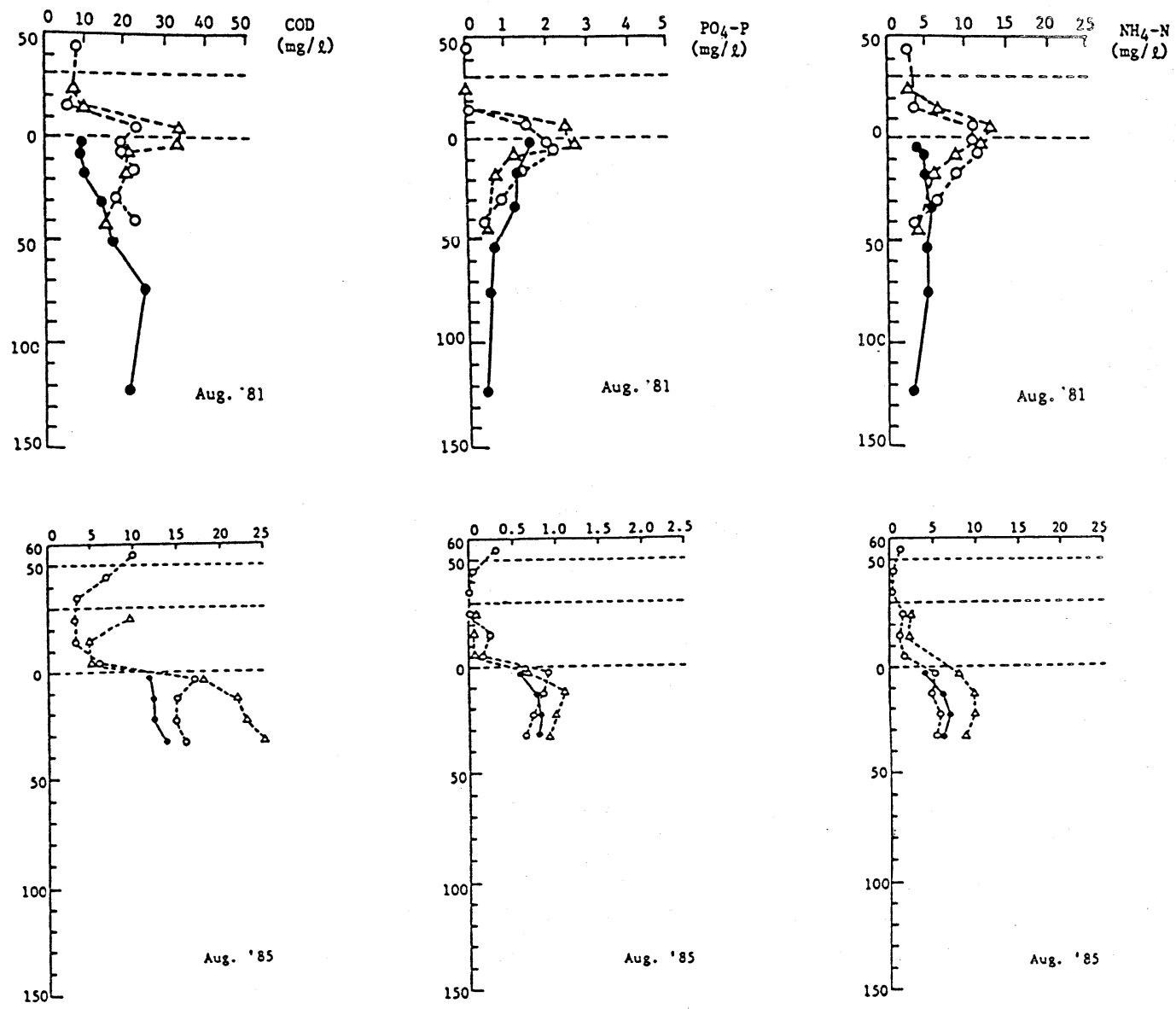

図-8 覆砂区域内外の底泥間隙水の水質の鉛直分布の経時変化

(2) 溶出速度

覆砂区域内外における底泥からの溶出速度の経時変化（現地試験）を図一9に示す。CODについては明確な奻果は みられないが、栄養塭については、覆砂区域外の溶出速度が区域内の溶出速度を上回り、覆砂による溶出削減奻果が 鼠められる。特にPの溶出削減奻果がめざましい。 
（3）底生生物

覆砂区域内外における底生生物の種類数及び個体数の経時変化を図一10に示す。西砂区域内の底生生物の種類数、 個体数は、区域外に比べて高くなっており、夏堨に低下する㑯向を示すものの、その後の回復は速く覆砂による生物 生育環境が改善されていることがわかる。
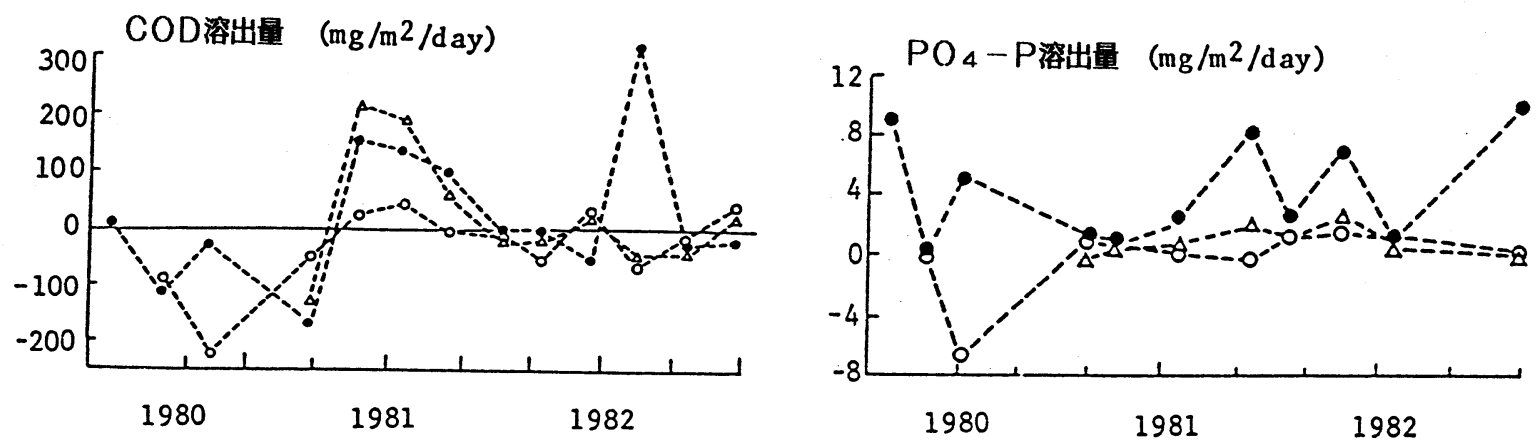

圀-9 覆砂区域内外の底泥からの溶出速度の変化（現地試騒）
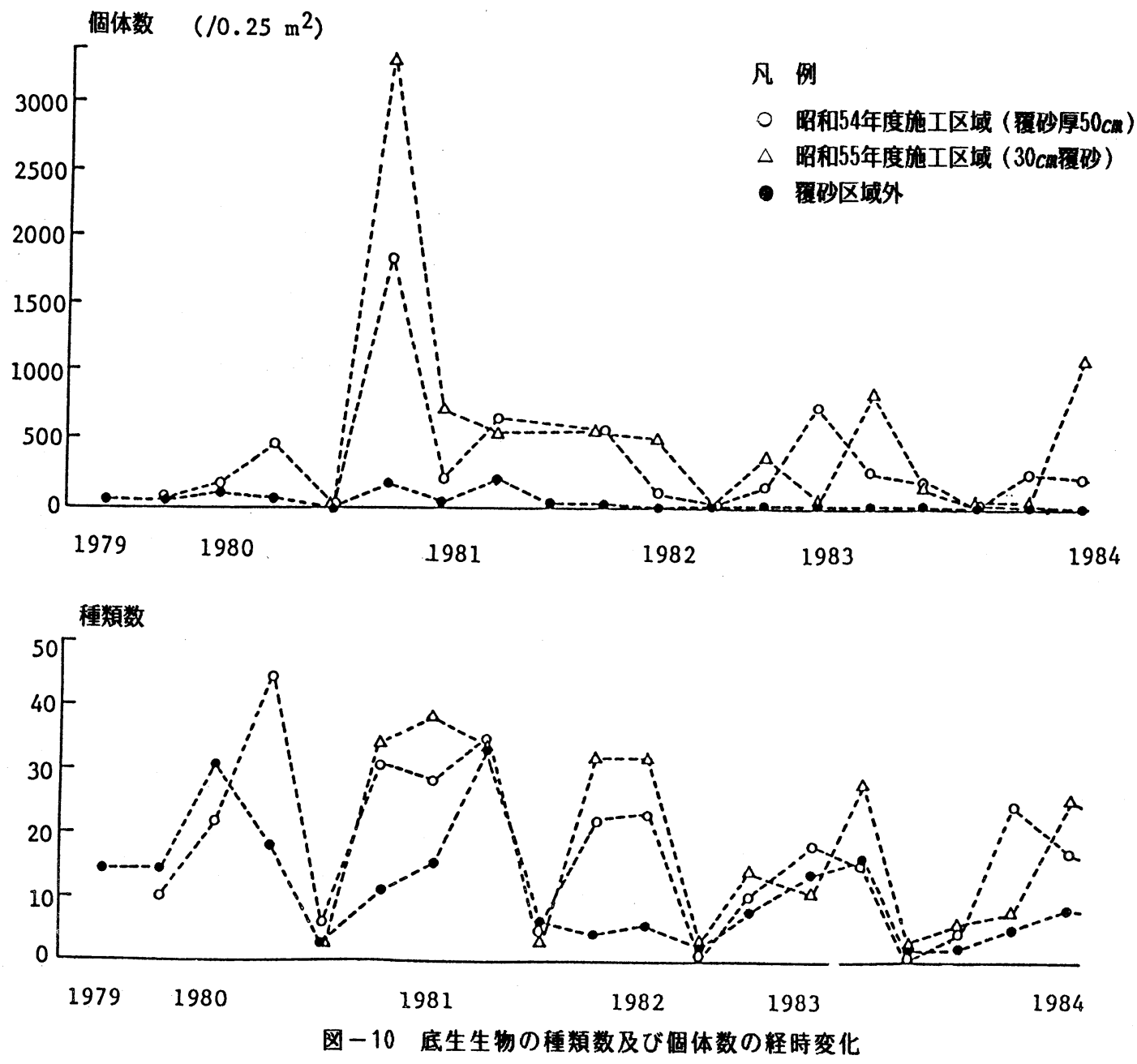

6. まとめ

吳湾における稪砂効果及びその持続性について要約すると以下のようになる。

(1)底質の含有量及び間隙水の浱度は、時間の経過とともに、表層においてやや高くなっているが、全体的には低い 值を保っている。

(2底泥からの溶出速度については、覆砂区域内の值は、区域外の值を下回っている。

(3)底生生物は、覆砂直後、驚異的に回復しており、その後回復量は減っているものの、区域外に比べて有為性を保 っている。

以上のように、底質改善効果、溶出削隇奻果及び生物相回復効果について、奻果及び持続性が踣ね検証された。

今後、底質浄化事業の実施にあたって解決すべき課題として、水質改善効果の把挃、生態系改善奻果の把晊、浮泥 流入防止対策の検討等が考えられる。 